\title{
Content of Language Cultural Universal in Cross-Cultural Communication
}

Oksana V. Rtischeva*

Kemerovo State Institute of Culture and the Arts 17 Voroshilova Str., Kemerovo, 650029, Russia

Received 20.03.2017, received in revised form 10.09.2018, accepted 24.09.2018

The study considers the issues of language cultural universals in cross-cultural communication. Moreover the study focuses attention on conventional somatic idioms as an example of language cultural universals which can have the main characteristics of cultural universals. As follows from the study people use idioms to make their language richer and more colorful and to convey subtle shades of meaning or intention. Somatic idioms are used often to replace a literal word or expression, and many times the idiom better describes the full nuance of meaning. Idioms and idiomatic expressions can be more precise than the literal words, often using fewer words but saying more. Thus, if languages go back the loans to one primary source, it is possible to speak about figurative and stylistic similarity of such idioms.

Keywords: language cultural universal, cross-cultural communication, idiom, somatic lexicon, conventional somatic idiom.

Research area: culturology.

Citation: Rtischeva, O.V. (2018). Content of language cultural universal in cross-cultural communication. J. Sib. Fed. Univ. Humanit. soc. sci., 12(1), 128-136. DOI: 10.17516/19971370-0333.

\section{Introduction}

Intervention of native culture, language and national consciousness in interpreting foreign culture communicative behavior and in own behavior at cross-cultural communication promotes some difficulties in cross-cultural communication. In other words, it is transfer of the national and cultural stereotypes of behavior typical for native language culture, on the communication process with representatives of other language cultures. And it leads to serious communicative mistakes and failures.

(C) Siberian Federal University. All rights reserved

* Corresponding author E-mail address: ortishheva@mail.ru

This work is licensed under a Creative Commons Attribution-NonCommercial 4.0 International License (CC BY-NC 4.0). 
Interest in what is a barrier in communication between representatives of different language cultures and often the reason of failures in cross-cultural communication has arisen long ago.

Barriers are determined as the problems arising in interaction and reducing its efficiency. Traditionally the following types of the communicative barriers arising in cross-cultural communication may be marked out: linguistic barriers, barriers in nonverbal communication and stereotypes. But a specific role in cross-cultural communication belongs to cultural hindrances such as distinctions of mentalities and national natures; discrepancy of language pictures of the world; influence of cultural stereotypes; distinctions in valuable reference points; discrepancy of cultural and language regulations; mistakes in humor perception; distinctions in communicative strategies; specific forms and ways for nonverbal communication.

But barriers in the cross-cultural sphere are not only an obligatory, but also necessary factor for establishing interaction between language culture communities. The main function of cross-cultural barriers is not to divide, but to regulate interaction between the communicating cultures. The constructive role of cross-cultural barriers is to help keeping national originality, on the one hand, (it is especially important for globalization era and establishing multicultural community), and on the other, to stimulate interest in foreign culture society because lack of a barrier often depreciates object of knowledge. Thus, barriers aren't a barrier between cultures; they are an additional incentive to communication.

In addition cultural universal plays rather large role in implementing successful communication.

\section{Theoretical framework. The idioms as a content of cultural universal}

Cultural universal is such regulations, values, rules, traditions and properties which are inherent in all cultures, irrespective of the geographical place, historical time and a social society organization.

In 1959 the American sociologist and ethnographer George Murdock allocated more than 70 universals which are the general elements for all cultures, such as age gradation, sport, next-to-skin jewelry, a calendar, hygiene, community-based organization, cooking, labor co-operation, cosmology, courting, dances, decorative art, guessing, interpretation of dreams, division of labor, education, language and etc.

Cultural universals arise because all people, in whatever part of the world they live, are physically arranged equally, they have the same biological need and face 
common problems which the environment puts before mankind. People are born and die therefore all people have customs connected with the birth and death. As they lead joint life, they have a division of labor, dances, games, greetings and etc. In spite of the fact that different ethnos speak different languages, language is also carried to cultural universal. As language is an objective form of accumulation, preservation and transfer of human experience, the concept language has two interconnected values: 1) language in general, language as a certain class of sign systems; 2) concrete, so-called ethnic language - the concrete real-life sign system used in specific society in concrete time and concrete space.

Idioms can have characteristic signs of cultural universals. The idioms containing a component of somatic lexicon have a large number of these signs.

Somatic lexicon is one of universal lexical groups in any language. In linguistic using the term somatic is introduced for the first time by F.O. Vakk who concluded that somatic lexicon belongs to one of the most ancient layers of phraseology (Starykh, 2011: 80-85). The somatic idioms in scientific literature is traditionally understood as the idioms with leading or dependent component designating not only external physical shapes of a human body (head, arm, nose and etc.), but also elements of cardiovascular, nervous and other systems (blood, lien, brain, liver and etc.) (Siuein, 2013: 119-120). Interest in this type of idioms is caused by the following facts such as: firstly, steady units with somatic lexicon make about $25 \%$ of all phraseological fund, and also they have cultural specificities, thus they are important subject of the analysis; secondly, anthropocentrism of a language picture of the world is most brightly shown in the idioms (Golovnia, 2012: 49); thirdly, idioms represent national specific units of a language accumulating the cultural potential of people (Araeva, 2014: 110).

The somatic phraseology is actively studied both in synchronous, and in the comparative analysis, however its comparison in languages unrelated, far from each other is provided not enough (Volkova, Khueichzhi, 2012: 5). The problem of establishing essence, amount and borders of somatic lexicon is also very relevant in modern linguistics. Vauntraub R.M. in his works offers to differentiate somatic lexicon on natural and conventional from the point of view of their origin. Natural somatic lexicon, such as head, leg, hand, appeared in according of human thinking and therefore it is general for all languages, and conventional somatic lexicon, for example, soul in Russian) is connected with developing material and spiritual culture of each nation (Starykh, 2011: 80-85). Appealing to conventional somatic idioms not only shows national and cultural specifics of language, but also gives interesting and important 
material for translators. Therefore, the theoretical description and practical analysis of somatic idioms reveal not only language, but also cultural, national characteristics of the compared nations.

As an example, Russian and English idioms containing a component of natural somatic lexicon - parts of the body, are offered to consider. English and Russian idioms using somatic lexicon in the structure represent huge group. They have symbolical character and images understandable for the Russians and Englishmen, as using names of parts of a body in a figurative sense; the person tries to give more generous thoughts and to make statement more impressive. These idioms have increased interlingua similarity. This phenomenon can be explained in the following way; names of parts of a body exist in lexicon of all nations and are well studied by them. They have high degree of interlingua equivalence, and this fact isn't a consequence of loans by one people from languages of another, and is caused by mere coincidence. The idioms containing the following names of parts of a body as head, hair, eyes, teeth, heart and hand are especially often used.

Head. The concept of head is connected with the concept of eternity which in turn corresponds to the concepts of vital force and youth. Semasiological chain: head - sun sky - water - fire - earth - hand - woman (Makovski, 1996: 122). Also the concept contains quality, mental and physical abilities of the person. Therefore when the clever person is spoken about, the following idioms are used: in Russian, голова на плечах; голова на месте; голова варит; светлая голова; in English, to have one's head screwed on right, clear head. A silly person is characterized as the soft in the head person, in Russian, без царя в голове; зеленая голова; курья голова; голова дубовая; голова садовая; мозги набекрень. About an ardent person: in English, hot head; in Russian, горячая голова. About a cool person the Russians say хладнокровный человек and about a stubborn person: beat something into someone's head - вбить в голову. About the person in love: fall head over heels in love (with someone) - влюбиться до беспамятства. About difficult unclear situation the following idiom can be used: can't make heads or tails of something or someone.

Eyes. The main part of information passes through eyes. They have mysterious and magic force. The sun and the moon in mythologies of many nations were considered as eyes of a powerful god. Therefore some people could have an evil eye: in Russian, это сглазу; кто-то сглазил; недобрый глаз поглядел; in English, a devil eye. Eyes had physical and spiritual abilities: in Russian, очи (beautiful, big and expressive eyes), видеть внутренним оком, очи души; in English, an eagle eye; in Russian, 
зоркий, орлиный глаз; fishy eye - тусклый, безжизненный взгляд; glad eye многообещающий взгляд; and single eye - целеустремленность, честность; to have got eyes like a hawk; to have eyes to see smth. - быть наблюдательным; and private - сыщик. Sometimes persons perform operations by means of eyes: окинуть глазами; обвести глазами; отвести глаза; смерить глазами; провожать глазами; таращить глаза; прищуривать глаз; смотреть во все глаза; to catch smb.'s eye привлечь чей-либо взгляд; not to take eye from smb. - любоваться кем-либо или чем-либо; one's eyes stand out of one's heard - глаза на лоб полезли; with all one's eyes - во все глаза; to make sheep's eyes at smb. - смотреть на кого-либо преданно, влюбленно; see eye to eye - сходиться во взглядах. Eyes can deceive: пускать пыль в глаза; замазать глаза - do smb. in the eye; in a pig's eye - ври больше, вот еще выдумал; to have an eye to the main chance - преследовать корыстные цели.

Hand. Being the main instrument of production and reproduction, the hand had phallic symbolic, and on beliefs of pagans this beginning correlated to lungs therefore a hand can correspond to breathe and spirit. Various movements of a hand, a provision of hands in relation to a body and fingers on the relation to each other in the ancient time had magic value, symbolizing the good and evil (Makovski, 1996: 280). A hand can be a symbol of the power and wealth (also the wealth purchased not by fair means): иметь руку; правая рука; влиятельная рука; at first hand; have long hands, free hand. Греть руки; запускать руку во что-либо; дать на лапу; залезть в чужой карман; clean hands, an open hand, put one's hand in one's pocket. Hands can characterize the person: руки-крюки - bad hand at smth.; стреляный воробей, тертый калач - old bird; мастер своего дела - crack hand at. People can swear on oath using hands: положа руку на сердце; ударить по рукам - give smb. one's hand on smth.

Heart. In Indo-European languages the concept heart indicates centrality. In Russian and English language pictures of the world the person can feel and experience emotions with the help of heart (Pimenova, 1999: 119). Heart is the center of life in general: physical, mental, spiritual and sincere. On the one hand, heart is a place for meeting God, on the other hand, heart is a source of sin. One more mytheme - archetype of heart is to be a soul receptacle. Heart reflects moral qualities of the person: in Russian, положа руку на сердце; каменное сердце; золотое сердце; доброе сердце; in English, big heart; harden one's heart, hard heart каменное сердце; light heart, легкий человек; heart of oak, храброе сердце; and heart of gold, золотое сердце; keep a good heart, не падать духом; an open heart, открытый человек. Heart is the place of feelings, an intuition and desires: по сердцу; с замиранием сердца; в сердце 
вспыхнула любовь, надежда; сердце чует; сердце подскажет; закрадываться в сердце; сердце кровью обливается; от всего сердца; разбить сердце; сердце (душа) ушло в пятки; heart (soul) went to heels, from the heart, make smb.'s heart bleed; lose one's heart, влюбиться; have smth. at heart; have one's heart in smth., вкладывать всю душу; have one's heart in one's boots, душа ушла в пятки; move smb.'s heart; one's heart is broken разбитое сердце.

Beard. In the ancient time the beard was considered as a symbol of courage, force, wisdom, magic, miracle force and fertility. Slavs thought the beard could perform guarding functions (Makovski, 1996: 52). Oath: клянусь бородой Пророка - Ву the beard of Prophet. To deceive, sneer: смеяться в кулак; усмехаться в усы - to laugh at smb.'s beard.

Nose. The main meaning: nose of the person. The nose acts as the main means of communication with the world around that corresponds also to ideas of primitive people of smells who used aromas and the burned victims to communicate with God. Nose is considered as a part of the body being able to perceive information: about a curious man, we can use the Russian idiom сунуть нос; about the sad person is possible to say in Russian вешать нос. No other part of a body has such power over the person as a nose. It is enough to get access to manage someone's nose so to have an opportunity to operate the person. Logically the idiom водить за нос corresponds to this thesis. An experienced person usually has a nose for smth. - иметь хороший нюх, наметанный глаз, держать нос по ветру. About very close standing people: nose to nose - нос к носу. Sometimes the nose is represented as independently functioning living being: before one's nose - куда глаза глядят; bite smb.'s nose - огрызнуться, оборвать кого-либо грубо; a bloody nose - поражение, разгром; follow one's nose идти прямо вперед; to put one's nose in - появиться; to rub smb's nose in it - ткнуть кого-либо носом; on the nose - тютелька в тютельку; a nose of wax - тряпка, как воск в чьих-либо руках; with one's nose in the air - задирающий нос; to put smb.'s nose out - утереть кому-либо нос.

Mouth. By means of a mouth the speech is made. It is also its symbolical value in the compared languages: to keep one's mouth shut - заткнуть рот. People use their mouth for many things. They eat, talk, shout and sing. There are many expressions using the word mouth. For example, if the person is said bad things about, the person might protest: do not bad mouth me - не очерняйте меня. Sometimes, people say something to a friend or family member that they later regret because it hurts that person's feelings: I really put my foot in my mouth this time - на сей раз я что-то 
ляпнул не подумавши. When someone falsely claims another person said something. The other person might protest - не приписывайте мне чужих слов. Information is often spread through word of mouth - через сарафанное радио. Sometimes when one person is speaking, he says the same thing that his friend was going to say. When this happens, the friend might say: you took the words right out of my mouth - ты предвосхитил мои слова. Sometimes a person has a bad or unpleasant experience with another person. He might say that experience left a bad taste in my mouth оставило неприятный привкус во рту. Sometimes people have lots of money because they were born into a very rich family. There is an expression for this: was born with a silver spoon in his mouth - родился с серебряной ложкой во рту.

Teeth. Teeth are the most ancient emblem of aggressive and protective force. For example, if the person wants to take vengeance on enemy, he can use the following expressions: an eye for an eye, a tooth for a tooth - око за око, зуб за зуб. These expressions coincide in both languages, in English and Russian. Just the same with the following idioms: armed to the teeth - вооружён до зубов.

Tongue. Language symbolizes communication and information transfer; it is its first symbolical sense, for example: to have lost one's tongue - язык проглотить. Often in the idioms the tongue presents excessive garrulity: wag one's tongue - языком трепать/чесать

Hair. Hair can be considered as a possible attribute of the head and also independently. Usually the word as a part of the idiom gains value of any emotion. For example, fear: one's hair stood on end - волосы дыбом встают.

\section{Conclusion}

Thus, the image of the person is imprinted forever in the idioms because in the center of the world there is a person as the personality having a body, soul and the speech. The ancient people realized the man as an anthropomorphous embodiment of the Universe. By means of the idioms which images are similar in Russian and English and also which aren't translated literally but they are realized rethought, realizing the language and culture is increased. Studying the idioms containing a component of natural somatic lexicon helps to understand culture and life of the nations; to consider primary forms for adapting the person to surrounding reality; that is to consider basic archetypes which are the cornerstone for interpreting the world by the person. They have an effect on all spheres of the person's activity, but they are most of all shown in his everyday life. On the example of the considered idioms it is possible to realize 
distinctly, how the idioms of modern English and Russian languages are various and expressive, and their similarity in figurative and stylistic coloring is caused by coincidence of basic archetypes of the national cultures.

\section{References}

Araeva, L.A. (2004). Slovoobrazovatel'nyi tip: traditsionnoe i sovremennoe videnie [Word-formation type: traditional and modern vision]. In Vestnik Moscovskogo Universiteta [Bulletin of Moscow University], 4, 110-115.

Fedorova, A.I. (1995). Frazeologicheski slovar' russkogo literaturnogo iazyka kontsa XIX-XX v.v. [Phraseological dictionaryof Russian literary language of the end of the $19^{\text {th }}$ the beginning $20^{\text {th }}$ century]. Moscow, Topikal, $608 \mathrm{p}$.

Golovnia, A.I. (2012). Kontseptual'noe pole leksemy ruka v russkoi I kitaiskoi naivnykh kartinakh mira (na materiale frazeologizmov) [Conceptual field for lexeme hand in Russian and Chinese language pictures of the world(on the material of idioms)]. In Karpovskie nauchnye chtenia [Karpov scientific readings], 6, 49-52.

Gul'tiaeva, A.V., Denisova, E.S. (2015). Osobennosti vospriatia somaticheskoi frazeologii (na material russkogo I kitaiskogo iazykov) [Perception features of somatic idioms (on the material of Russian and Chinese languages]. In Vestnik Kemerovskogo gosudarstvennogo universiteta [Bulletin of Kemerovo State University], 4 (64), 65-69.

Lenets, E.Z. (2007). Konventsional'nye frazeologizmy s somaatizmami $v$ sovremennom frantsuzkom iazyke. Posobie po kursu «Lexicologia frantsuzkogo iazyka» [Conventional somatic idioms in modern French language. Teacher's guide for course "Lexicology of French language”]. Grodno, 24-25.

Makovski, M.M. (1996). Sravnitel'nyi slovar' mifologicheskoi symvoliki $v$ indoevropeiskikh iazykakh: obraz mira I miry obrazov [Comparative dictionary of mythological symbolic in Indo-European languages: image of the world and worlds of images]. Moscow, 416.

Pimenova, M.V. (1999). Etnogermenevtika iazykovoi naivnoi kartiny vnutrennego mira cheloveka [Ethno hermeneutics of the language picture of the world for the person's insight world]. Kemerovo, Kuzbassvuzizdat, 262 p.

Siuein, Ch. (2013). Issledovania semanticheskikh osobennostei frazeologizmov s komponentami-somatizmami [Researching semantic peculiarities of the somatic idioms]. In Filologia $i$ chelovek [Philology and a person], 4, 119-126.

Starykh, O.V. (2011). Somatizmy kak osobyi klass slov v leksicheskoi sisteme tserkovnoslavianskogo iazyka [Somatic lexicon as a special type of words in lexical 
system of Church Slavonic language]. In Vestnik Pravoslavnogo Sviato-Tikhonovskogo gumanitarnogo universiteta [Bulletin of Orthodox St. Tikhonovski Humanitarian University], 2 (24), 80-85.

Volkova, N.N., Khueichzhi, Ch. (2012). Frazeologizmy so slovom «ruka» v russkom i kitaiskom iazykakh [The idioms with the word "hand" in Russian and Chinese]. In Vestnik Voronezhskogo gosudarstvennogo universiteta [Bulletin of Voronezh State University], 333-338. Available at: http://www.rki-phil-vsu.ru/sborniki/ soderzhanije_2012.rtf (accessed: 22. 03. 2015).

\section{Содержание языковых культурных универсалий в межкультурной коммуникации}

O.В. Ртищева

Кемеровский государственный институт культуры Россия, 650029, Кемерово, ул. Ворочилова, 17

В статье рассматриваются вопросы языковых культурных универсалий в межкультурной коммуникации. Особое внимание уделяется конвенциональным соматическим фразеологизмам, которые могут обладать признаками культурных универсалий. Исходя из рассматриваемого материала, фразеологизмы в русском и английском языках используются для более полной и выразительной передачи оттенков значений. Поэтому их сходство в образной и стилистической окраске обусловлено совпадением базисных архетипов национальных культур.

Ключевые слова: языковые культурные универсалии, межкультурная коммуникачия, фразеологизмы, соматическая лексика, конвенциональная соматическая лексика.

Научная специальность: 24.00.00 - культурология. 